\title{
A Closer Look at 804: A Summary of Considerations for DoD Program Managers
}

Stephany Bellomo

December 2011

SPECIAL REPORT

CMU/SEI-2011-SR-015

Acquisition Support Program

http://www.sei.cmu.edu

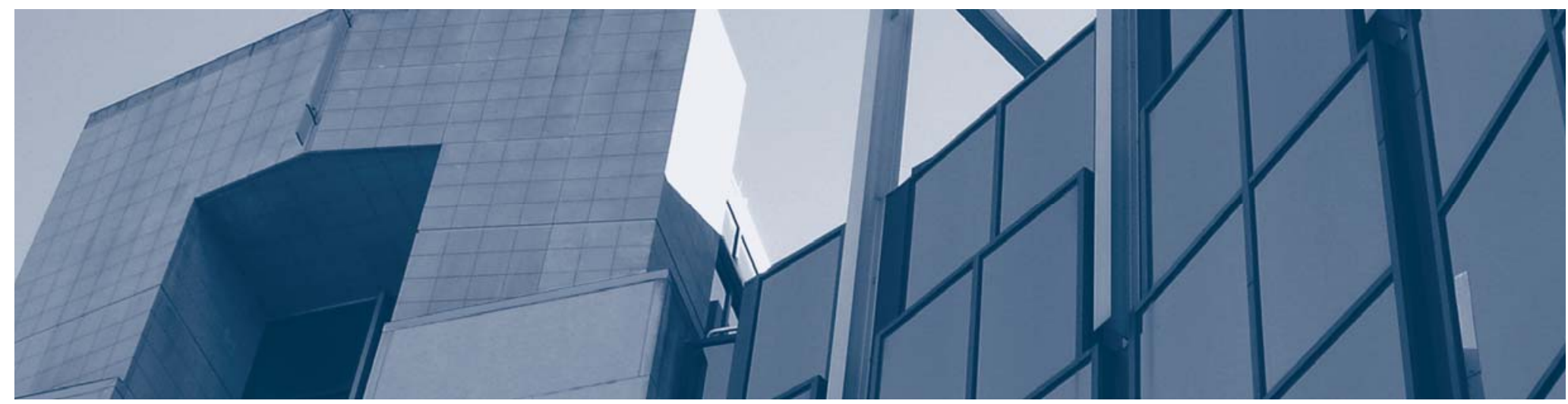


Copyright 2011 Carnegie Mellon University

This material is based upon work funded and supported by the United States Department of Defense under Contract No. FA8721-05-C-0003 with Carnegie Mellon University for the operation of the Software Engineering Institute, a federally funded research and development center.

Any opinions, findings and conclusions or recommendations expressed in this material are those of the author(s) and do not necessarily reflect the views of the United States Department of Defense.

This report was prepared for the

SEI Administrative Agent

ESC/CAA

20 Schilling Circle, Building 1305, $3^{\text {rd }}$ Floor

Hanscom AFB, MA 01731-2125

\section{NO WARRANTY}

THIS CARNEGIE MELLON UNIVERSITY AND SOFTWARE ENGINEERING INSTITUTE MATERIAL IS FURNISHED ON AN “AS-IS” BASIS. CARNEGIE MELLON UNIVERSITY MAKES NO WARRANTIES OF ANY KIND, EITHER EXPRESSED OR IMPLIED, AS TO ANY MATTER INCLUDING, BUT NOT LIMITED TO, WARRANTY OF FITNESS FOR PURPOSE OR MERCHANTABILITY, EXCLUSIVITY, OR RESULTS OBTAINED FROM USE OF THE MATERIAL. CARNEGIE MELLON UNIVERSITY DOES NOT MAKE ANY WARRANTY OF ANY KIND WITH RESPECT TO FREEDOM FROM PATENT, TRADEMARK, OR COPYRIGHT INFRINGEMENT.

This material has been approved for public release and unlimited distribution except as restricted below.

Internal use:* Permission to reproduce this material and to prepare derivative works from this material for internal use is granted, provided the copyright and "No Warranty" statements are included with all reproductions and derivative works.

External use:* This material may be reproduced in its entirety, without modification, and freely distributed in written or electronic form without requesting formal permission. Permission is required for any other external and/or commercial use. Requests for permission should be directed to the Software Engineering Institute at permission@sei.cmu.edu.

TM Carnegie Mellon Software Engineering Institute (stylized), Carnegie Mellon Software Engineering Institute (and design), Simplex, and the stylized hexagon are trademarks of Carnegie Mellon University.

* $\quad$ These restrictions do not apply to U.S. government entities. 


\section{Table of Contents}

Abstract

Executive Summary

viii

1 Introduction

1.1 Background

1.2 Brief Overview

1.3 Scope

2 National Defense Authorization Act, Section 804

2.1 Applicability

2.2 Key Dates

2.3 Overview

2.4 Program Management Impacts Based on This Guidance

3 Interim Acquisition Guidance for Defense Business Systems Released November 2010

3.1 Applicability

3.2 Key Dates

3.3 Overview

3.4 Business Capability Lifecycle

3.5 Program Management Impacts Based on This Guidance

4 DoD Response to 804: A New Approach for Delivering Information Capabilities in the Department of Defense

4.1 Applicability

4.2 Key Dates

4.3 Overview

4.4 Program Management Impacts Based on This Guidance

5 Section 804 Program Manager Considerations Summary Table

6 Continued Work on 804 and IT Acquisition Task Force

$7 \quad$ Closing Thoughts

Acronym List

Appendix A: National Defense Authorization Act 2010, Section 804

Appendix B: National Defense Authorization Act 2011, Section 804 
CMU/SEI-2011-SR-015 | ii 


\section{List of Figures}

Figure 1: Defense Science Board Recommended Acquisition Process [Ren 2010] 5

Figure 2: $\quad$ BCL Acquisition Business Model [Interim Report 2010] 6

Figure 3: $\quad$ Defense Science Board Recommended Acquisition Process II [Ren 2010] 10 
CMU/SEI-2011-SR-015 | iv 


\section{List of Tables}

Table 1: Summary of DoD 804-Related Program Manager Considerations 


\section{Abstract}

This report examines Section 804 National Defense Authorization Act (NDAA) for 2010 and related guidance documents through the lens of the Department of Defense (DoD) Information Technology (IT) Program Manager. The information in this report is intended to help the program manager reason about actions they may need to take to adapt and comply with the Section 804 NDAA for 2010 and associated guidance. 
CMU/SEI-2011-SR-015 | vii 


\section{Executive Summary}

In this report, we look at Section 804 National Defense Authorization Act (NDAA) for 2010 and related guidance documents, at the time this report was written, through the lens of the Department of Defense (DoD) Information Technology (IT) program manager. It is the author's hope that this information will enable the program manager to reason about building expertise, changing internal processes, and leveraging new toolsets to adapt to the new IT acquisition process.

In the first part of this report, the author analyzes three IT acquisition-related documents. For each document, the author provides a brief summary of the contents of the document followed by key program management implications. The documents analyzed in this report include:

- $\quad$ Section 804 National Defense Authorization Act for 2010

- Interim Acquisition Guidance for Defense Business Systems (DBS) released November 2010

- A New Approach for Delivering Information Capabilities in the Department of Defense released November 2010

Section 5 contains a roll up of the program manager implications from each section of this paper into a summary table titled "DoD 804-Related Program Manager Considerations.” The paper concludes with a summary of ongoing work related to IT acquisition reform and closing thoughts. 


\section{Introduction}

\subsection{Background}

At the request of Congress, the Defense Science Board (DSB) conducted a study released in March 2009 to evaluate the current acquisition process for Information Technology (IT) systems in the DoD. The output of the study was a report proposing that the Undersecretary of Defense create a new acquisition process for IT systems based on commercial worldwide best practices [DSB 2009]. The study pointed out that the new process should foster industry standard practices, such as requiring continuous user participation throughout the software lifecycle and mandating iteration-driven software development approaches.

In response to the DSB recommendation, Congress passed the Section 804 National Defense Authorization Act (NDAA) for 2010, which called for the Under Secretary of Defense, Dr. Ashton B. Carter, to develop and implement a new acquisition process for IT systems [Ren 2010]. Carter then released an Interim Acquisition Guidance for Defense Business Systems on November 15, 2010. This guidance provided program managers with a transitional IT acquisition process while they waited for the new IT acquisition process to be released.

The DoD then released a report titled, A New Approach for Delivering Information Capabilities in the DoD, in which the Secretary of Defense, responding to Section 804, provides an update on DoD's progress towards developing a new IT acquisition process. In the "New Approach" report, the Under Secretary of Defense provides some rough implementation guidelines, as well as generalized set of system categories for program managers to leverage in trying to determine whether the new IT acquisition process applies or not.

This report looks at these important documents from the perspective the program manager responsible for responding to the impact of the proposed changes on their program(s).

\subsection{Brief Overview}

The purpose of this report is to help the DoD IT System Program Managers reason about what actions they may need to take to adapt and comply with the Section 804 NDAA for 2010 and associated guidance.

This report contains an analysis of the following documents:

- Section 804 NDAA for 2010

- Interim Acquisition Guidance for Defense Business Systems (DBS) released November 2010

- A New Approach for Delivering Information Capabilities in the Department of Defense released Nov 2010 
The sections in the body of this report follow a consistent format with the following subsections:

- Applicability (to whom the guidance is applicable)

- Key Dates (key dates identified in the report or directive)

- Overview (brief description of the report or directive)

- Program Management Impacts related to the Guidance

Section 5 of this paper contains a consolidation of the program manager implications from each section into a combined summary table titled “DoD Program Manager Considerations". The paper concludes with a summary of ongoing work.

\subsection{Scope}

Section 804 NDAA for 2010 has sweeping implications for DoD programs across the entire IT acquisition lifecycle. It covers the investment review stage through to the various activities within the engineering phase (i.e., requirements, design, testing). We are not going to cover all potential impacts across the entire acquisition landscape in this paper. We have scoped this report to focus on topics relevant to the DoD IT Program Manager and the software development lifecycle. Therefore, we focused special attention on the phase after the business case/investment review phase, the engineering phase, and topics related to the engineering phase. This includes topics related to managing and executing the development of software-intensive IT systems.

Related topics that are out of scope for this paper include:

- business case development

- investment review

- governance

- policy

- operations and sustainment

In the next section, we begin our brief overview of the contents of Section 804 NDAA for 2010. 


\section{National Defense Authorization Act, Section 804}

In this section, we briefly summarize the Section 804 NDAA for 2010.

\subsection{Applicability}

Section 804 NDAA for 2010 directs the Secretary of Defense to implement a new acquisition process for IT systems.

\subsection{Key Dates}

This section summarizes any key dates specified in the Section 804 NDAA for 2010 guidance. This Act specifies that the Secretary of Defense must submit a report to Congress no later than 270 days after the date of the enactment of the Act, December 2010.

\subsection{Overview}

This section provides a brief overview of the Act. Congress approved the Section 804 NDAA for 2010 titled "Implementation of New Acquisition Process for Information Technology Systems" in December 2010. Highlights from this Act are paraphrased in the following paragraphs. Because these concepts are relatively new within the DoD, the directive at this stage is relatively brief and vague. The Act specifies that the Secretary of Defense shall provide a report to Congress that:

- describes the new acquisition process and provides an explanation for any decision by the Secretary to deviate from the criteria

- defines paragraphs (1) and (2) of subsection (a) of Section 804 NDAA for 2010

- $\quad$ provides a schedule for the implementation of the new acquisition process

- identifies the categories of information technology acquisitions to which such process will apply

- $\quad$ and includes the Secretary's recommendations for any legislation that may be required to implement the new acquisition process [NDAA 2010].

Appendix A provides the full text of the Section 804 NDAA for 2010.

\subsection{Program Management Impacts Based on This Guidance}

The directive is very short; however, its four key bullets have broad and sweeping implications for the IT Program Manager. They specify that the new process shall foster:

- early and continual involvement of the user

- multiple, rapidly executed increments or releases of capability

- $\quad$ early, successive prototyping to support an evolutionary approach

- a modular, open-systems approach 


\section{Interim Acquisition Guidance for Defense Business Systems Released November 2010}

On November 15, 2010, Dr. Ashton B. Carter released an "Interim Acquisition Guidance for Defense Business Systems (DBS).” The intent of this guidance was to provide a transitional acquisition process for DoD programs to use until the new IT acquisition process is released.

\subsection{Applicability}

The DBS specifies that the interim guidance is applicable to:

- the Office of Secretary of Defense

- the military departments

- the Office of the Chairman of the Joint Chiefs of Staff (CJCS) and the Joint Staff

- the Combatant Commands

- the Office of the Inspector General of the Department of Defense

- the Defense Agencies

- the DoD Field Activities

- and all other organizational entities within the DoD

The DBS also specifies the dollar-value threshold for the applicability of a new process called the Business Capability Lifecycle (BCL). The interim guidance states that the BCL shall apply to each defense business system with a total modernization cost over $\$ 1,000,000$.

\subsection{Key Dates}

This guidance states that its effective date is November 2010, and that the directive will remain in effect until formally incorporated into DoD Instruction (DoDI) 5000.02 [Interim Report 2010].

\subsection{Overview}

As expected in an interim guidance document, this directive straddles the new and the old acquisition processes. For example, it suggests a beta release concept and at the same time requires full operational test and evaluation (OT\&E) for the beta release. This raises the question, "What is the difference between a beta and non-beta release if a Beta requires full OT\&E?” Clearly, this is interim guidance that is trying to move in the direction of new acquisition concepts, but is still holding rather tightly to the old.

The interim guidance describes changes to each of the following phases (shown in Figure 1):

- Business Capability Definition/Investment Review

- Architectural Development and Risk Reduction (Prototypes)

- Development and Demonstration

- Operations and Support 
A significant portion of this guidance document focuses on the impact to the Business Case Analysis and development phase. Consequently, there is less focus on the Architectural Development and Risk Reduction phase, Development and Demonstration phase, and Operations and Support phase. The focus area for this guidance document is shown in the figure below.

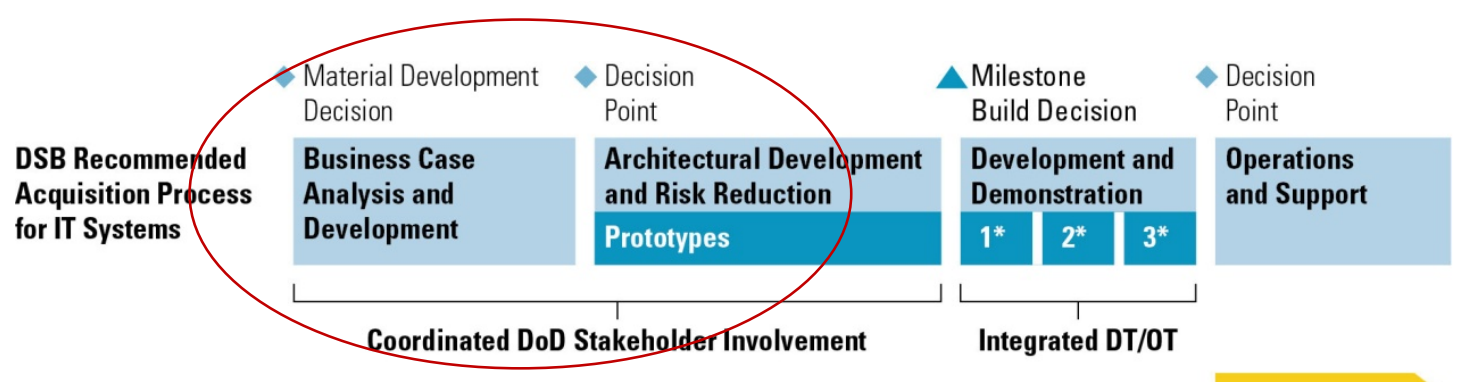

Figure 1: Defense Science Board Recommended Acquisition Process [Ren 2010]

Although the guidance is short, it is impactful. This interim guidance states that programs shall incorporate the following:

- Incremental Approach-An approved business need shall be divided into discrete, fully funded, and manageable increments and shall adhere to the maximum requirements for an increment (specified in this guidance).

- Independent Assessment-An independent risk assessment shall be performed prior to Milestone A and Milestone B and serve as input for the investment review board review.

- BCL Acquisition Business Model—The BCL shall be used as the model acquisition process for DBS. The guidance provides procedures for meeting BCL and DBS requirements [Interim Report 2010].

\subsection{Business Capability Lifecycle}

The most significant part of the directive for the program manager in the interim guidance is probably the requirement to use the BCL model as the new acquisition process for defense business systems (until the new process is finalized). The guidance doesn't apply to all programs, however. The guidance specifies that the BCL shall apply to each DBS that has a total modernization cost over $\$ 1,000,000$.

BCL merges three major DoD processes:

1. CJCSI 3170.01G, Joint Capabilities Integration and Development System (JCIDS)

2. DoDI 5000.02 Operation of the Defense Acquisition System (DAS)

3. Investment Review Board (IRB) / Defense Business System Management Committee (DBSMC) governance bodies for defense business capabilities and systems

The BCL acquisition business model (see Figure 2) supports the implementation of BCL and depicts the phases, milestones, and decision points of the BCL acquisition process. 

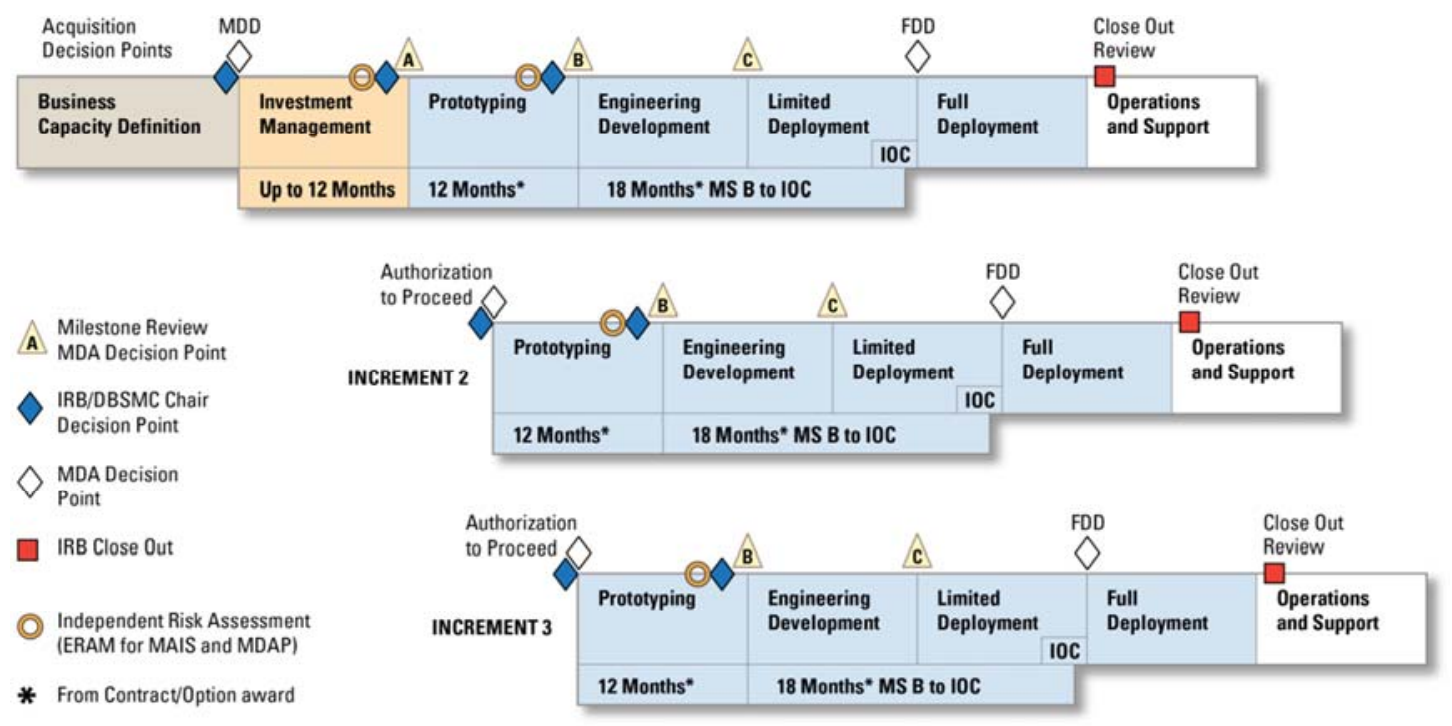

Figure 2: BCL Acquisition Business Model [Interim Report 2010]

Key attributes of BCL include

- streamlined capability documentation

- $\quad$ streamlined governance and tiered accountability

- independent risk assessment

- flexibility in capability implementation strategies

- emphasis on the use of mature technologies

- use of "time constrained" process management and program execution

- capability delivery in increments of 18 months or less

- $\quad$ user and test communities engagement throughout the lifecycle [New Approach 2010]

\subsection{Program Management Impacts Based on This Guidance}

As mentioned earlier in this section, a significant portion of this guidance is focused on the phases prior to the Development and Demonstration Phase such as the Investment Review/Business Case Development phases. Since this phase is largely out of the program manager's control, the bullet list below provides a condensed list of directives from the guidance that specifically affect the program manager's sphere of influence.

To help organize and reason about the impact on program managers, these areas of impact are grouped into the following categories: Planning and Portfolio Management, Prototyping, Requirements and Architecture, Development and Execution, Testing, Project Monitoring and Reporting. 
Planning and Portfolio Management

- 18 months specified as maximum time that shall elapse between contract full deployment

- Initial Operating Capability must be achievable within 5 years

Prototyping, Requirements and Architecture

- Prototyping shall be used as a continuous discovery and development process reflecting close collaboration between the functional sponsor and the system developer

- Knowledge gained during prototyping may result in changes to the requirements

- Funding for prototyping activities must be approved by the milestone decision authority

Testing

- The guidance introduces the concept of the Limited Deployment Phase in which limited number of users get access to a new "beta" release and test it in an operational environment

- The Limited Deployment Phase entrance criteria is defined as a developmentally-tested, production-representative system, and ready for initial operational test and evaluation

Development and Execution

- Requires that at Full Deployment Decision, the milestone decision authority shall review the business case and the independent operational testing and evaluation results and make recommendations whether the capability is ready to proceed to full deployment

Project Monitoring and Reporting

- Specifies each increment shall include a close-out review

- Explains that the close-out review enables understanding of how well a completed increment meets the needs of users before finalizing the requirements for a subsequent increment

The next section describes the Secretary of Defense's response to Section 804 NDAA for 2010. 


\section{DoD Response to 804: A New Approach for Delivering Information Capabilities in the Department of Defense}

The next piece of information related to 804 is a report titled, “A New Approach for Delivering Information Capabilities in the DoD”. This is the Secretary of Defense's response to Section 804 NDAA for 2010.

\subsection{Applicability}

While the new process is applicable across all DoD IT systems, this report specifies that the new IT acquisition process does not apply to all categories of systems. The report states that the new acquisition process is applicable to the following types of systems:

Networked IT Systems (e.g., command and control, business information)

- user-facing applications

- computing infrastructure (e.g., common applications, operating system)

- security and information assurance for applications, systems, and networks

- computing hardware including configuration modification for network integration, etc. (e.g., servers, laptops)

- communications/networking infrastructure

Note: IT hardware requiring unique development and requisite production decisions will be acquired using traditional DoD acquisition policy ( $D o D 5000$ processes) to ensure appropriate focus on these areas.

Weapon Platform IT Systems

- $\quad$ platform-hosted IT mission systems that are not considered embedded

Note: IT embedded in weapon systems will continue to be developed, acquired, and managed as part of that weapon platform and not separately acquired under the new IT acquisition process. Upgrades to embedded IT software in weapon systems may be considered for applicability to the new IT acquisition process when no hardware change is required.

Services acquired or developed as a service-oriented architecture [New Approach 2010] 


\subsection{Key Dates}

This report does not provide specific implementation dates; however, it does provide a rough implementation schedule summarized as follows.

Near-term schedule requirements:

- designate initial pilot projects (new start projects and existing programs) aligned within each broad portfolio

- initiate aspects of the new process not requiring legislative changes

- determine and implement project performance-tracking metrics and tools

- $\quad$ engage with industry associations to gather their input in developing the new process

- define the organizational structure and designate portfolios within the information enterprise

- complete development of the project templates

- develop DoD policy issuances to apportion roles and responsibilities, authorities, and accountabilities within the new process

- define platform standards and common test and integration capabilities in consultation with the DoD CIO

- develop interim training curriculum and initiate training

- exploit existing mechanisms for execution year resourcing flexibility

- $\quad$ develop legislative proposal for FY12

Mid-term schedule requirements:

- expand set of pilot projects to fine-tune the new processes and initiate pilot portfolio

- further develop training curriculum and expand staff training

- $\quad$ submit proposed legislative changes for FY12

\subsection{Overview}

The report titled “A New Approach for Delivering Information Capabilities in the DoD” is the Secretary of Defense's response to Section 804 NDAA for 2010 and provides an update on DoD's progress towards developing a new acquisition process for information technology systems. The report highlights that significant and fundamental change is needed across the department's IT acquisition processes, with synchronized and risk-scaled requirements, resourcing, acquisition management and oversight in order to deliver rapid IT capabilities where they are needed most [Press Release 2010]. 
This section includes

- a description of the new acquisition process

- explanations of deviations from the DSB report

- an implementation schedule

- identification of the applicable categories of IT

- recommendations for legislative change considerations [New Approach 2010]

Contrary to the interim guidance, where significant focus is placed on areas such as Business Case Analysis and Development, the focus of this guidance is on the Development and Demonstration Phase.

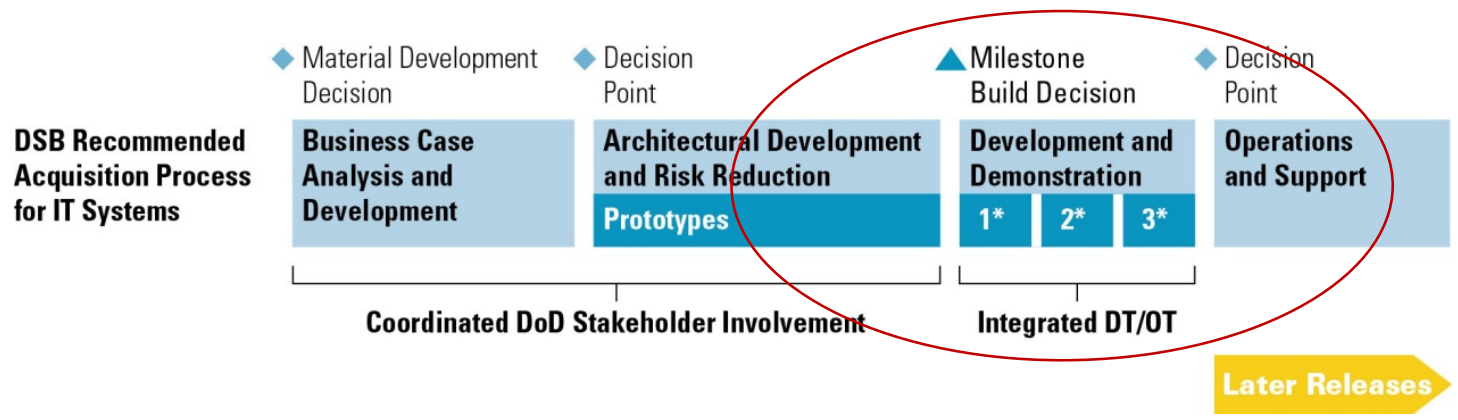

Figure 3: Defense Science Board Recommended Acquisition Process II [Ren 2010]

In the New Approach report, the IT task force defined several principles to guide the department's approach to IT acquisition including:

- Deliver early and often: This principle is aimed at changing the culture from one that is focused typically on a single delivery to a new model that comprises multiple deliveries to establish an environment that supports deployed capabilities every 12 to 18 months.

- Incremental and iterative development and testing: This principle embraces the concept that incremental and iterative development and testing, including the use of prototyping, yield better outcomes than trying to deploy large, complex IT network systems in one big bang.

- Rationalized requirements: User involvement is critical to the ultimate success of any IT implementation, and user needs must be met. However, this principle also recognizes the need for users and requirements developers to embrace an enterprise focus across a portfolio of capabilities with established standards and open modular platforms that offer customized solutions to ensure interoperability and seamless integration.

- Flexible and tailored processes: The department's IT needs range from modernizing nuclear command and control systems to updating word processing systems on office computers. This principle acknowledges unique types of IT acquisition and embraces flexible and tailoredand risk-appropriate- IT paths based on the characteristics of the proposed IT acquisition.

- Knowledgeable and experienced IT workforce: This task force recognizes that a top priority is to establish a cadre of trained professionals and that the lack thereof is a significant impediment to successful implementation of any future process [New Approach 2010]. 


\subsection{Program Management Impacts Based on This Guidance}

As mentioned in the overview for this section, a significant portion of this guidance is focused on the Engineering Phase (Development and Demonstration Phase). A condensed list of directives from the guidance related to the program manager is provided below. The directives are grouped into these broad categories: Planning and Portfolio Management, Requirements, Architecture, Development and Execution, Testing, Project Monitoring and Reporting.

Planning and Portfolio Management

- New approaches should embrace the value of "80 percent solutions" (as appropriate).

- There are different types of systems and multiple acquisition processes are needed to address the differences in these types of systems.

- Projects executed in a timeboxed manner deliver capability more rapidly.

- Capabilities shall be deployed every 12-18 months and functionality that cannot be delivered within timeboxed constraints may be deferred.

- Planning for IT capability will require sequencing of prioritized capabilities.

- Portfolio and project management processes will move from large multi-year programs to portfolios of short-duration projects.

- More emphasis on timely coordination and quicker decision-making will be delegated to lower levels for smaller projects, but with accountability mechanisms for senior-level decisionmaking.

- A multi-level planning approach will be used, with a multi-year roadmap and a 12 month detailed release plan.

- Investment approach will fund multiple time-boxed, overlapping projects.

- Team members of interrelated projects will provide incremental iterative IT capability improvements through frequent upgrades.

Prototyping, Requirements and Architecture

- Requirements management process will be adjusted to reflect timeboxed development constraints and allow for uncertainty.

- Initial requirements will be defined at the mission level in broad, measurable terms that are not expected to change (e.g., appropriate cyber security controls, data standards, process flows, architecture, and minimum system specific key performance).

- Prioritization and further definition of requirements will be an ongoing activity.

- Tools and methods will be furnished to prioritize requirements and facilitate user feedback.

- Users from joint or service/agency organizations will be designated to serve as requirements leads to participate in oversight reviews.

- Enterprise focus, established standards, and open modularity will drive and constrain designs to ensure interoperability and seamless integration.

- Multi-year roadmap and detailed release plans will be supported by business and technical architectures and standards. 
- Development efforts shall allow for user-determined priorities.

Development and Execution

- As applicable, innovative approaches such as user-centered design, feature-driven developments, and other proven IT practices should be considered.

- Development efforts will focus on what can be achieved in the short term.

- Development efforts shall be based on low-risk technology.

- Continuous user engagement will be emphasized throughout the process.

- Development, when necessary, will include prototyping and maturity assessment activities.

Testing

- Development will involve continual test and evaluation with user involvement.

- Test and evaluation will be structured to support iterative and incremental delivery.

- Testing approaches will make extensive use of prototyping and automated testing.

- Testing will be integrated with certification and accreditation activities.

- Testing processes will leverage in-situ testing on beta versions prior to release.

- Integrate existing test infrastructure into a persistent, virtual, service-based environment.

Project Monitoring and Reporting

- Increase the stakeholder involvement through more frequent performance-based, in-process reviews.

- Tangible evidence of relevant development capabilities in the form of prototypes or deployed systems ("working software") will have preference in an evaluation with a commensurate decrease in paper-based proposal components.

- Traditional milestone reviews to initiate major DoD 5000 program phases will be realigned to address milestone decision points.

- These milestone decision points will be conducted as in-process reviews for decision-makers to obtain real-time program status for acquisition decisions.

- In earlier phases of the acquisition, stakeholder reviews should be calendar-based events, while later phases should link such reviews with iterations or delivery of capability.

- Project status and execution information will be available electronically, replacing paperbased reporting.

- Documentation will be consolidated.

Workforce/Other

- Acquiring highly trained IT professionals is a top priority.

- Outreach to industry will be conducted to gain insight into commercially driven industry trends. 


\section{Section 804 Program Manager Considerations Summary Table}

This section contains a consolidated summary of the program manager implications from each of the previous sections. The summary table is organized according to following columns: Category (specifies a general grouping concept), Directive, Source (source document), and PM Considerations. Many of items in the PM Considerations column were derived from the report titled "Considerations for Using Agile in DoD Acquisition” [Lapham 2010].

Table 1: Summary of DoD 804-Related Program Manager Considerations

\begin{tabular}{|c|c|c|c|}
\hline Category & Directive & Source(s) & PM Considerations \\
\hline \multirow[t]{5}{*}{$\begin{array}{l}\text { Overarching } \\
\text { Themes }\end{array}$} & $\begin{array}{l}\text { Early and continual } \\
\text { involvement of the user }\end{array}$ & $\begin{array}{l}\text { NDAA Section } \\
804 \text { FY 2010, A } \\
\text { New Approach: } \\
\text { Guiding Principles }\end{array}$ & $\begin{array}{l}\text { How will you involve the user in prototyp- } \\
\text { ing? } \\
\text { How will you involve the user in require- } \\
\text { ments? } \\
\text { How will you involve the user in testing } \\
\text { activities? }\end{array}$ \\
\hline & $\begin{array}{l}\text { Incremental and iterative } \\
\text { development and testing }\end{array}$ & $\begin{array}{l}\text { NDAA Section } \\
804 \text { FY 2010, } \\
\text { New Approach: } \\
\text { Guiding Principles }\end{array}$ & $\begin{array}{l}\text { Do planning processes support iterative } \\
\text { planning? } \\
\text { Do you have a way to determine whether } \\
\text { system functionality can be divided to } \\
\text { support iterative releases (e.g., architec- } \\
\text { tural dependency analysis) [arch de- } \\
\text { pendency] } \\
\text { Does the development team have exper- } \\
\text { tise and tools to develop software incre- } \\
\text { mentally (e.g., Agile, etc.) } \\
\text { What criteria will be used to decide which } \\
\text { increments will be released to the user } \\
\text { community and which will be "internal } \\
\text { demos"? } \\
\text { Will testing criteria for an iteration re- } \\
\text { lease be different from traditional testing } \\
\text { criteria? } \\
\text { Will testing processes vary for internal } \\
\text { versus external releases? }\end{array}$ \\
\hline & $\begin{array}{l}\text { Early, successive proto- } \\
\text { typing to support an } \\
\text { evolutionary approach }\end{array}$ & $\begin{array}{l}\text { NDAA Section } \\
804 \text { FY } 2010\end{array}$ & $\begin{array}{l}\text { Do you have prototyping environments? } \\
\text { Are prototyping environments separate } \\
\text { from your production and testing envi- } \\
\text { ronments for "beta testing"? }\end{array}$ \\
\hline & $\begin{array}{l}\text { A modular, open- } \\
\text { systems approach }\end{array}$ & $\begin{array}{l}\text { NDAA Section } \\
804 \text { FY } 2010\end{array}$ & $\begin{array}{l}\text { Do you have common definition for mod- } \\
\text { ular, open systems agreed upon by the } \\
\text { contractor and program office? } \\
\text { How do you measure modular, open } \\
\text { system capability? }\end{array}$ \\
\hline & $\begin{array}{l}\text { Flexible/Tailored pro- } \\
\text { cesses: Unique types of } \\
\text { IT acquisition and sys- } \\
\text { tem characteristics re- } \\
\text { quire different processes }\end{array}$ & $\begin{array}{l}\text { New Approach } \\
\text { Report; Guiding } \\
\text { Principles }\end{array}$ & $\begin{array}{l}\text { Do you know the differentiating charac- } \\
\text { teristics between systems? } \\
\text { How do you decide which acquisition } \\
\text { process to use? } \\
\text { What do you need to tailor IT acquisition } \\
\text { processes? }\end{array}$ \\
\hline
\end{tabular}




\begin{tabular}{|c|c|c|c|}
\hline Category & Directive & Source(s) & PM Considerations \\
\hline & $\begin{array}{l}\text { Knowledgeable and } \\
\text { Experienced IT Work- } \\
\text { force }\end{array}$ & $\begin{array}{l}\text { New Approach } \\
\text { Report; Guiding } \\
\text { Principles }\end{array}$ & $\begin{array}{l}\text { Do you have staff with experience man- } \\
\text { aging systems development in an incre- } \\
\text { mental and iterative way? } \\
\text { Is your contractor able to develop in an } \\
\text { iterative and incremental way? }\end{array}$ \\
\hline & $\begin{array}{l}\text { Processes must recog- } \\
\text { nize the value of } 80 \\
\text { percent solutions and } \\
\text { development shall focus } \\
\text { on what can be } \\
\text { achieved in the short } \\
\text { term leveraging "low-risk } \\
\text { technology" }\end{array}$ & $\begin{array}{l}\text { New Approach } \\
\text { Report }\end{array}$ & $\begin{array}{l}\text { Do you have a way to determine what } \\
80 \% \text { of functionality is critical? } \\
\text { If you focus on short term, how do you } \\
\text { plan for infrastructure and architecture } \\
\text { components on which short term needs } \\
\text { depend? } \\
\text { How do you define "low risk technology" } \\
\text { on your program? }\end{array}$ \\
\hline \multirow[t]{5}{*}{$\begin{array}{l}\text { Planning, Portfo- } \\
\text { lio Management } \\
\text { \& Funding }\end{array}$} & $\begin{array}{l}\text { Max time that shall } \\
\text { elapse between contract } \\
\text { initiation and full de- } \\
\text { ployment is } 18 \text { months } \\
\text { and Initial Operating } \\
\text { Capability (IOC) must be } \\
\text { achievable within } 5 \\
\text { years; Usable function- } \\
\text { ality delivered every six } \\
\text { months (Fed } \mathrm{CIO} \text { ) }\end{array}$ & $\begin{array}{l}\text { Interim Guidance, } \\
\text { New Approach } \\
\text { Report, 25 Point } \\
\text { Plan (Fed ClO) }\end{array}$ & $\begin{array}{l}\text { Can your development team support a } 6 \text { - } \\
\text { month delivery cycle if it is mandated? } \\
\text { What are the risks to doing this? } \\
\text { Can you deliver full capability deploy- } \\
\text { ment in } 18 \text { months? } \\
\text { Is IOC achievable in } 5 \text { years? If not, what } \\
\text { actions do you need to take (e.g., re- } \\
\text { scoping, add resources, etc.) }\end{array}$ \\
\hline & $\begin{array}{l}\text { Planning for IT capability } \\
\text { will require sequencing } \\
\text { of prioritized capabilities }\end{array}$ & $\begin{array}{l}\text { New Approach } \\
\text { Report }\end{array}$ & $\begin{array}{l}\text { How does your planning processes sup- } \\
\text { port prioritizing, by features or capabili- } \\
\text { ties? } \\
\text { Do you have strong change processes } \\
\text { for arbitrating priorities between conflict- } \\
\text { ing stakeholders? }\end{array}$ \\
\hline & $\begin{array}{l}\text { Portfolio and project } \\
\text { management processes } \\
\text { will move from large } \\
\text { multi-year programs to } \\
\text { portfolios of short- } \\
\text { duration projects; A } \\
\text { multi-level planning } \\
\text { approach will be used; } \\
\text { multi-year roadmap and } \\
\text { a } 12 \text { month detailed } \\
\text { release plan }\end{array}$ & $\begin{array}{l}\text { New Approach } \\
\text { Report }\end{array}$ & $\begin{array}{l}\text { Do you have portfolio management pro- } \\
\text { cesses and expertise to manage many } \\
\text { short-duration projects? } \\
\text { Do you have a multi-year "portfolio-level" } \\
\text { roadmap? } \\
\text { Do you have a } 12 \text { month detailed release } \\
\text { plan? }\end{array}$ \\
\hline & $\begin{array}{l}\text { More emphasis on } \\
\text { quicker decision making; } \\
\text { Decisions will be dele- } \\
\text { gated to lower levels for } \\
\text { smaller projects }\end{array}$ & $\begin{array}{l}\text { New Approach } \\
\text { Report }\end{array}$ & $\begin{array}{l}\text { What decisions will be delegated to lower } \\
\text { levels? Will contractor be able to make } \\
\text { more decisions? } \\
\text { What industry management practices } \\
\text { might you leverage to promote dynamic } \\
\text { decision making? (e.g., Scrum) }\end{array}$ \\
\hline & $\begin{array}{l}\text { Investment approach } \\
\text { will fund multiple time- } \\
\text { boxed, overlapping } \\
\text { projects }\end{array}$ & $\begin{array}{l}\text { New Approach } \\
\text { Report }\end{array}$ & $\begin{array}{l}\text { What dependencies will there be be- } \\
\text { tween the "overlapping" projects in the } \\
\text { portfolio? } \\
\text { Will there be common infrastructure and } \\
\text { components in overlapping projects? } \\
\text { Will projects have to "compete" for fund- } \\
\text { ing? }\end{array}$ \\
\hline
\end{tabular}









\begin{tabular}{|c|c|c|c|}
\hline Category & Directive & Source(s) & PM Considerations \\
\hline & $\begin{array}{l}\text { nical architectures and } \\
\text { standards }\end{array}$ & & $\begin{array}{l}\text { What process will be used to approve } \\
\text { and communicate common architecture } \\
\text { components? }\end{array}$ \\
\hline \multirow[t]{8}{*}{$\begin{array}{l}\text { Development \& } \\
\text { Testing }\end{array}$} & $\begin{array}{l}\text { Development and test- } \\
\text { ing, when necessary, } \\
\text { will include prototyping } \\
\text { and maturity assess- } \\
\text { ment activities }\end{array}$ & A New Approach & $\begin{array}{l}\text { How do you decide what to prototype? } \\
\text { What processes will be used for maturity } \\
\text { assessment? Do they support iterative } \\
\text { development? }\end{array}$ \\
\hline & $\begin{array}{l}\text { Development, Test and } \\
\text { evaluation will be struc- } \\
\text { tured to support iterative } \\
\text { and incremental delivery } \\
\text { with user involvement }\end{array}$ & A New Approach & $\begin{array}{l}\text { How to you plan for incremental testing? } \\
\text { What does a continuous test process } \\
\text { look like? What industry examples can } \\
\text { be leveraged? } \\
\text { How does this compare to traditional } \\
\text { Operation Test \& Evaluation? }\end{array}$ \\
\hline & $\begin{array}{l}\text { Testing approaches will } \\
\text { make extensive use of } \\
\text { automated testing }\end{array}$ & A New Approach & $\begin{array}{l}\text { Do you have automated test tools? } \\
\text { Does your team know what to automate } \\
\text { and what not to automate? } \\
\text { Do you have expertise to build test } \\
\text { scripts? }\end{array}$ \\
\hline & $\begin{array}{l}\text { Testing will be integrat- } \\
\text { ed with certification and } \\
\text { accreditation activities }\end{array}$ & A New Approach & $\begin{array}{l}\text { How do you generate data needed to } \\
\text { meet certification and accreditation re- } \\
\text { quirements in an iterative, incremental } \\
\text { lifecycle? }\end{array}$ \\
\hline & $\begin{array}{l}\text { Integrate existing test } \\
\text { infrastructure into a } \\
\text { persistent, virtual, ser- } \\
\text { vice-based environment }\end{array}$ & A New Approach & $\begin{array}{l}\text { Does your testing approach and infra- } \\
\text { structure support service-based testing? } \\
\text { Is your system designed to leverage } \\
\text { service-based testing? }\end{array}$ \\
\hline & $\begin{array}{l}\text { Each increment shall } \\
\text { include a close-out re- } \\
\text { view to gain understand- } \\
\text { ing of how well a com- } \\
\text { pleted increment meets } \\
\text { the needs of users }\end{array}$ & Interim Guidance & $\begin{array}{l}\text { What is included in an increment close- } \\
\text { out review? } \\
\text { How will you measure how well the in- } \\
\text { crement meets user needs? (e.g., satis- } \\
\text { faction survey) }\end{array}$ \\
\hline & $\begin{array}{l}\text { Introduce Limited De- } \\
\text { ployment Phase in } \\
\text { which limited number of } \\
\text { users get access to a } \\
\text { new "beta" release; } \\
\text { Entrance criteria, as per } \\
\text { the SecDef Interim } \\
\text { guidance, requires sys- } \\
\text { tem to be ready for initial } \\
\text { operational test and } \\
\text { evaluation }\end{array}$ & $\begin{array}{l}\text { Interim Guidance, } \\
\text { A New Approach }\end{array}$ & $\begin{array}{l}\text { Will this be a separate environment from } \\
\text { the development/integration test envi- } \\
\text { ronment? } \\
\text { How will you gather and incorporate } \\
\text { changes generated from user testing? } \\
\text { What is the difference between the } \\
\text { OT\&E requirements for limited deploy- } \\
\text { ment phase and full deployment phase } \\
\text { (guidance makes it sound like they are } \\
\text { the same)? }\end{array}$ \\
\hline & $\begin{array}{l}\text { At Full Deployment } \\
\text { Decision, the milestone } \\
\text { decision authority shall } \\
\text { review the Business } \\
\text { Case, the IOT\&E results } \\
\text { and DOT\&E recommen- } \\
\text { dations whether the } \\
\text { capability is ready to } \\
\text { proceed to full deploy- } \\
\text { ment }\end{array}$ & Interim Guidance & $\begin{array}{l}\text { What iteration will be considered "full } \\
\text { deployment"? } \\
\text { What does "full deployment" in an itera- } \\
\text { tive lifecycle mean? } \\
\text { What are IOT\&E criteria in a "continuous } \\
\text { integration context"? }\end{array}$ \\
\hline
\end{tabular}




\begin{tabular}{|c|c|c|c|}
\hline Category & Directive & Source(s) & PM Considerations \\
\hline \multirow[t]{6}{*}{$\begin{array}{l}\text { Project Monitor- } \\
\text { ing and Report- } \\
\text { ing }\end{array}$} & $\begin{array}{l}\text { Traditional milestone } \\
\text { reviews to initiate major } \\
\text { DoD } 5000 \text { program } \\
\text { phases will be realigned } \\
\text { to frequent perfor- } \\
\text { mance-based milestone } \\
\text { decision points }\end{array}$ & $\begin{array}{l}\text { New Approach } \\
\text { Report }\end{array}$ & $\begin{array}{l}\text { What activities will be conducted at fre- } \\
\text { quent milestone decision point as op- } \\
\text { posed to traditional milestones? (e.g., } \\
\text { demos)? } \\
\text { What will be used to measure perfor- } \\
\text { mance? }\end{array}$ \\
\hline & $\begin{array}{l}\text { These milestone deci- } \\
\text { sion points will be con- } \\
\text { ducted as in-process } \\
\text { reviews for decision- } \\
\text { makers to obtain real- } \\
\text { time program status for } \\
\text { acquisition decisions }\end{array}$ & $\begin{array}{l}\text { New Approach } \\
\text { Report }\end{array}$ & $\begin{array}{l}\text { How is "in-process review" defined? } \\
\text { What data will be collected and used for } \\
\text { decision-making? }\end{array}$ \\
\hline & $\begin{array}{l}\text { Tangible evidence of } \\
\text { relevant development } \\
\text { capabilities in the form } \\
\text { of prototypes or de- } \\
\text { ployed systems ("work- } \\
\text { ing software") will have } \\
\text { preference in an evalua- } \\
\text { tion with a commensu- } \\
\text { rate decrease in paper- } \\
\text { based proposal compo- } \\
\text { nents }\end{array}$ & $\begin{array}{l}\text { New Approach } \\
\text { Report }\end{array}$ & $\begin{array}{l}\text { How will you evaluate "working software" } \\
\text { in an RFP evaluation? } \\
\text { How will you get access to prototypes? } \\
\text { What criteria will you use to judge the } \\
\text { software? } \\
\text { How will you evaluate whether the pro- } \\
\text { posed architecture is good? }\end{array}$ \\
\hline & $\begin{array}{l}\text { In earlier phases of the } \\
\text { acquisition, stakeholder } \\
\text { reviews should be cal- } \\
\text { endar-based events, } \\
\text { while later phases } \\
\text { should link such reviews } \\
\text { with iterations or deliv- } \\
\text { ery of capability }\end{array}$ & $\begin{array}{l}\text { New Approach } \\
\text { Report }\end{array}$ & $\begin{array}{l}\text { Which activities will be calendar-based } \\
\text { versus delivery based? (e.g., require- } \\
\text { ments reviews) }\end{array}$ \\
\hline & $\begin{array}{l}\text { Project status and exe- } \\
\text { cution information will be } \\
\text { available online replac- } \\
\text { ing paper-based report- } \\
\text { ing }\end{array}$ & $\begin{array}{l}\text { New Approach } \\
\text { Report }\end{array}$ & $\begin{array}{l}\text { Will the tools to publish project status be } \\
\text { provided by the enterprise, portfolio or } \\
\text { project? } \\
\text { What project status information makes } \\
\text { sense for an iterative development ap- } \\
\text { proach? }\end{array}$ \\
\hline & $\begin{array}{l}\text { Documentation will be } \\
\text { consolidated into fewer } \\
\text { documents }\end{array}$ & $\begin{array}{l}\text { New Approach } \\
\text { Report }\end{array}$ & $\begin{array}{l}\text { What documents do you still need? } \\
\text { How do you determine what is important } \\
\text { to document about the system? }\end{array}$ \\
\hline \multirow[t]{2}{*}{$\begin{array}{l}\text { Technical Out- } \\
\text { reach }\end{array}$} & $\begin{array}{l}\text { Outreach to industry will } \\
\text { be conducted to gain } \\
\text { insight into commercially } \\
\text { driven industry trends }\end{array}$ & $\begin{array}{l}\text { New Approach } \\
\text { Report }\end{array}$ & $\begin{array}{l}\text { Do you collaborate with FFRDCs and } \\
\text { Industry to learn about successful indus- } \\
\text { try/DoD practices? }\end{array}$ \\
\hline & $\begin{array}{l}\text { As applicable, innova- } \\
\text { tive approaches such as } \\
\text { user-centered design, } \\
\text { feature-driven develop- } \\
\text { ments, and other proven } \\
\text { IT practices should be } \\
\text { considered }\end{array}$ & A New Approach & $\begin{array}{l}\text { Do you have a chief architect or some- } \\
\text { one identified that keeps up with innova- } \\
\text { tive solutions? }\end{array}$ \\
\hline
\end{tabular}

The next section describes some of the continued related work in this area. 


\section{Continued Work on 804 and IT Acquisition Task Force}

Work has continued in the area of DoD acquisition reform since the directives and guidance documents covered in this paper were written. After the release of the 2010 Section 804 guidance directive, Congress continued to focus on acquisition reform by releasing the 2011 National Defense Authorization Act titled "Review of Acquisition Process for Rapid Fielding of Capabilities in Response to Urgent Operational Needs.”

This Act contains two major directives summarized below. These directives primarily focused on making sure programs adopt the new processes and that work in the area of developing the new IT acquisition processes continues to evolve and mature.

1. The first directive was a required review of the acquisition process as described in the response by the Secretary of Defense to the 2010 Act. This Act specified that "Not later than one year after the date of the enactment of this Act, the Secretary of Defense shall complete a review of the process for the fielding of capabilities in response to urgent operational needs and submit a report on the review to the congressional defense committees" [NDAA 2011].

2. The second directive was a review process examining which systems/programs are appropriate for the new acquisition process versus the traditional 5000.02 process. The 2011 Act specified that "Not later than 270 days after the date of the enactment of this Act the Secretary shall develop and implement an expedited review process. This process shall determine whether capabilities proposed as urgent operational needs are appropriate for fielding or should be fielded through the traditional acquisition process" [NDAA 2011]. The full text for National Defense Authorization Act 2011, Section 804 is provided in Appendix B.

IT Acquisition Task Force, chaired by the Deputy Secretary of Defense and led by the Deputy Chief Management Officer (DCMO), was established to continue fleshing out the new IT acquisition process. The original Task Force participants included:

- Under Secretary of Defense for Acquisition, Technology \& Logistics (USD(AT\&L))

- Assistant Secretary of Defense for Networks and Information Integration/DoD Chief Information Officer (ASD(NII)/DoD CIO)

- Director for Cost Assessment and Program Evaluation (D,CAPE)

- Under Secretary of Defense Comptroller (USD(C))

- Director, Operational Test and Evaluation (DOT\&E)

- Under Secretary of Defense for Intelligence (USD(I))

- Joint Chiefs of Staff (JCS),

- Military Departments (MILDEPs)

The Task Force engages with Congress, the Government Accountability Office, and key stakeholders throughout the Department and industry to further define and implement the new process in accordance with this report. [New Approach 2010] 
The DoD and Federal CIO are also collaborating and continue to share ideas. Vivek Kundra, U.S. Chief Information Officer released the 25 Point Implementation Plan on the same day the report, A New Approach for Delivering Information Capabilities in the Department of Defense, was released. Many of the concepts being promoted by the Federal CIO are consistent with the concepts in the DoD directives (and vice versa).

Some highlights of the Federal CIO 25 Point Implementation Plan include the following:

- Turnaround or terminate one-third of underperforming projects in IT portfolio.

- Shift to cloud first policy.

- Reduce number of federal data centers by at least 800 by 2015 .

- Major IT programs must have a dedicated program manager and use specialized IT acquisition professionals.

- Use a modular approach with usable functionality delivered every six months.

- Work with Congress to consolidate commodity IT funding under the Agency CIOs, and develop flexible budget models that align with modular development.

- Launch an interactive platform for pre-RFP agency-industry collaboration [Kundra 2010].

The next section contains some closing thoughts related to IT acquisition reform and ongoing research in this area. 


\section{Closing Thoughts}

At the time of writing this summary, the 804 guidance for the new DoD IT acquisition process is still in its early stages of maturity. While the good news is the new guidance acknowledges the need for DoD software acquisition processes outside of the DoD 5000.02 traditional waterfallbased approach, the bad news is the new DoD IT acquisition process is still largely undefined. So, program managers will have to fill in the gaps for a while.

In many cases, the guidance is clearly straddling the waterfall approach to managing IT acquisitions while trying to also encourage adoption of a new acquisition process. This is a challenging situation for program managers. While this straddling effect is expected for a period, it will become very burdensome if program managers have to adhere to two sets of competing processes for a long time. It is our hope that the new acquisition process will become better defined in the near future and that the transition period when old and new processes overlap will not be too long.

In reviewing the Section 804 directives, we identified several candidate focus areas for future work described below.

1. Categorization of systems and characteristics for the new acquisition process. While the "New Approach" report provides very high-level, rough categorization of systems that are appropriate for the IT acquisition process, there appears to be a need for continued work in this area. A more detailed, elaborated model is needed to reason about the acquisition process nuances necessary to deal with the wide variety of systems program managers are building today.

2. Further elaboration of the BCL engineering phases. While the BCL provides significant improvement in the areas of business case approval and investment review, further, more detailed, guidance is required for program managers to navigate the engineering phases (to include phases such as prototyping, requirements, architecture, development, and execution).

3. Leverage and incorporate industry practices. Successful industry and DoD incremental development practices should be leveraged and used as models for future IT acquisition process and practice development.

The SEI is currently working in these area and we hope to contribute to helping $\mathrm{DoD}$ and program managers adopt forward leaning acquisition processes and practices. 


\title{
Acronym List
}

\author{
BCL Business Capability Lifecycle \\ CIO Chief Information Officer \\ CJCS Chairman of the Joint Chiefs of Staff \\ DBS Defense Business System \\ DBSMC Defense Business System Management Committee \\ DSB Defense Science Board \\ IRB Investment Review Board \\ IT Information Technology \\ JCIDS Joint Capability Investment Development System \\ OT\&E Operational Test \& Evaluation
}




\section{Appendix A: National Defense Authorization Act 2010, Section 804}

(a) NEW ACQUISITION PROCESS REQUIRED—The Secretary of Defense shall develop and implement a new acquisition process for information technology systems. The acquisition process developed and implemented pursuant to this subsection shall, to the extent determined appropriate by the Secretary-

(1) be based on the recommendations in chapter 6 of the March 2009 report of the

Defense Science Board Task Force on Department of Defense Policies and Procedures for the Acquisition of Information Technology; and

(2) be designed to include-

(A) early and continual involvement of the user;

(B) multiple, rapidly executed increments or releases of capability;

(C) early, successive prototyping to support an evolutionary approach; and

(D) a modular, open-systems approach.

(b) REPORT TO CONGRESS-Not later than 270 days after the date of the enactment of this Act, the Secretary of Defense shall submit to the Committees on Armed Services of the Senate and the House of Representatives a report on the new acquisition process developed pursuant to subsection (a). The report required by this subsection shall, at a minimum-

(1) describe the new acquisition process;

(2) provide an explanation for any decision by the Secretary to deviate from the criteria established for such process in paragraphs (1) and (2) of subsection (a);

(3) provide a schedule for the implementation of the new acquisition process;

(4) identify the categories of information technology acquisitions to which such process

will apply; and

(5) include the Secretary's recommendations for any legislation that may be required to implement the new acquisition process. 


\section{Appendix B: National Defense Authorization Act 2011, Section 804}

From H. R. 6523

\section{SEC. 804. REVIEW OF ACQUISITION PROCESS FOR RAPID FIELDING OF CAPABILITIES IN RESPONSE TO URGENT OPERATIONAL NEEDS.}

(a) Review of Rapid Acquisition Process Required-

(1) IN GENERAL- Not later than one year after the date of the enactment of this Act, the Secretary of Defense shall complete a review of the process for the fielding of capabilities in response to urgent operational needs and submit a report on the review to the congressional defense committees.

(2) REVIEW AND REPORT REQUIREMENTS- The review pursuant to this section shall include consideration of various improvements to the acquisition process for rapid fielding of capabilities in response to urgent operational needs. For each improvement, the report on the review shall discuss--
(A) the Department's review of the improvement;
(B) if the improvement is being implemented by the Department, a schedule for implementing the improvement; and
(C) if the improvement is not being implemented by the Department, an explanation of why the improvement is not being implemented.

(3) IMPROVEMENTS TO BE CONSIDERED- The improvements that shall be considered during the review are the following:

(A) Providing a streamlined, expedited, and tightly integrated iterative approach to--

(i) the identification and validation of urgent operational needs;

(ii) the analysis of alternatives and identification of preferred solutions;

(iii) the development and approval of appropriate requirements and acquisition documents;

(iv) the identification and minimization of development, integration, and manufacturing risks;

(v) the consideration of operation and sustainment costs;

(vi) the allocation of appropriate funding; and

(vii) the rapid production and delivery of required capabilities.

(B) Clearly defining the roles and responsibilities of the Office of the Secretary of Defense, the Joint Chiefs of Staff, the military departments, and other components of the Department of Defense for carrying out all phases of the process.

(C) Designating a senior official within the Office of the Secretary of Defense with primary responsibility for making recommendations to the Secretary on the use of the authority provided by 
subsections (c) and (d) of section 806 of the Bob Stump National Defense Authorization Act for Fiscal Year 2003 (10 U.S.C. 2302 note), as amended by section 803 of this Act, in appropriate circumstances.

(D) Establishing a target date for the fielding of a capability pursuant to each validated urgent operational need.

(E) Implementing a system for--

(i) documenting key process milestones, such as funding, acquisition, fielding, and assessment decisions and actions; and

(ii) tracking the cost, schedule, and performance of acquisitions conducted pursuant to the process.

(F) Establishing a formal feedback mechanism for the commanders of the combatant commands to provide information to the Joint Chiefs of Staff and senior acquisition officials on how well fielded solutions are meeting urgent operational needs.

(G) Establishing a dedicated source of funding for the rapid fielding of capabilities in response to urgent operational needs.

(H) Issuing guidance to provide for the appropriate transition of capabilities acquired through rapid fielding into the traditional budget, requirements, and acquisition process for purposes of contracts for follow-on production, sustainment, and logistics support.

(I) Such other improvements as the Secretary considers appropriate.

(b) Discriminating Urgent Operational Needs From Traditional Requirements-

(1) EXPEDITED REVIEW PROCESS- Not later than 270 days after the date of the enactment of this Act, the Secretary shall develop and implement an expedited review process to determine whether capabilities proposed as urgent operational needs are appropriate for fielding through the process for the rapid fielding of capabilities or should be fielded through the traditional acquisition process.

(2) ELEMENTS- The review process developed and implemented pursuant to paragraph (1) shall(A) apply to the rapid fielding of capabilities in response to joint urgent operational need statements and to other urgent operational needs statements generated by the military departments and the combatant commands;

(B) identify officials responsible for making determinations described in paragraph (1);

(C) establish appropriate time periods for making such determinations;

(D) set forth standards and criteria for making such determinations based on considerations of urgency, risk, and lifecycle management;

(E) establish appropriate thresholds for the applicability of the review process, or of elements of the review process; and

(F) authorize appropriate officials to make exceptions from standards and criteria established under subparagraph (D) in exceptional circumstances.

(3) COVERED CAPABILITIES- The review process developed and implemented pursuant to paragraph (1) shall provide that, subject to such exceptions as the Secretary considers appropriate 
for purposes of this section, the acquisition process for rapid fielding of capabilities in response to urgent operational needs is appropriate only for capabilities that--

(A) can be fielded within a period of two to 24 months;

(B) do not require substantial development effort;

(C) are based on technologies that are proven and available; and

(D) can appropriately be acquired under fixed price contracts.

(4) INCLUSION IN REPORT- The Secretary shall include a description of the expedited review process implemented pursuant to paragraph (1) in the report required by subsection (a). 


\section{References}

\section{[Brown 2010]}

Brown, Nanette; Nord, Robert; \& Ozkaya, Ipek. "Enabling Agility Through Architecture,” Crosstalk, Nov/Dec (2010). www.crosstalkonline.org/issues/novemberdecember-2010.html

\section{[BTA 2010]}

Business Transformation Agency website, http://www.bta.mil/products/bcl.html

\section{[DSB 2009]}

Report of the Defense Science Board task force on Department of Defense policies and procedures for the acquisition of information Technology, Office of the Under Secretary of Defense for Acquisition, Technology, and Logistics, March 2009.

\section{[Interim Report 2010]}

Interim Acquisition Guidance for Defense Business Systems (DBS) released November 15, 2010. Acquisition Guidance for Defense Business Systems.pdf

\section{[Kundra 2010]}

Kundra, Vivek. 25 Point Implementation Plan to Reform Federal Information Technology Management. Section 804 Task force website

http://www.afei.org/WorkingGroups/section804tf/Pages/default.aspx

\section{[Lapham 2010]}

Lapham, Mary Ann; Williams, Ray; Hammons, Charles; Burton, Daniel; and Schenker, Alfred. Considerations for Using Agile in DoD Acquisition (CMU/SEI-2010-TN-002). Software Engineering Institute, Carnegie Mellon University, April 2010.

http://www.sei.cmu.edu/library/abstracts/reports/10tn002.cfm

\section{[NDAA 2010]}

National Defense Authorization Act for Fiscal Year 2010, 10 U.S.C., Pub. L. 111-84 § 804 (2009).

\section{[NDAA 2011]}

National Defense Authorization Act of 2011 (P. L. 111-383) Section 804SEC. 804.

\section{[New Approach 2010]}

A New Approach for Delivering Information Capabilities in the Department of Defense, the Section 804 Task force website http://www.afei.org/WorkingGroups/section804tf/Pages/default.aspx

\section{[Press Release 2010]}

Press Release: Report on New IT Acquisition Process Released. Dec 9, 2010.

dcmo.defense.gov/documents/Report_New_IT_Acquisition_Process.pdf

\section{[Ren 2010]}

Ren, Chiang H.; Busch, Stephen Col USAF (Ret.); \& Prebble, Matthew. Improving the Initiation of Acquisition Activities for Automated Information Systems. Defense Acquisition University, October 2010. http://www.dau.mil 


\begin{tabular}{|c|c|c|c|c|}
\hline \multicolumn{3}{|c|}{ REPORT DOCUMENTATION PAGE } & \multicolumn{2}{|c|}{$\begin{array}{l}\text { Form Approved } \\
\text { OMB No. 0704-0188 }\end{array}$} \\
\hline \multicolumn{5}{|c|}{$\begin{array}{l}\text { Public reporting burden for this collection of information is estimated to average } 1 \text { hour per response, including the time for reviewing instructions, search- }- \text { ind } \\
\text { ing existing data sources, gathering and maintaining the data needed, and completing and reviewing the collection of information. Send comments regard } \\
\text { ing this burden estimate or any other aspect of this collection of information, including suggestions for reducing this burden, to Washington Headquarters } \\
\text { Services, Directorate for information Operations and Reports, 1215 Jefferson Davis Highway, Suite 1204, Arlington, VA 22202-4302, and to the Office of } \\
\text { Management and Budget, Paperwork Reduction Project (0704-0188), Washington, DC 20503. }\end{array}$} \\
\hline $\begin{array}{l}\text { AGENCY USE ONLY } \\
\text { (Leave Blank) }\end{array}$ & \multicolumn{2}{|c|}{$\begin{array}{ll}\text { 2. } & \text { REPORT DATE } \\
& \text { December } 2011\end{array}$} & \multicolumn{2}{|c|}{$\begin{array}{l}\text { 3. REPORT TYPE AND DATES } \\
\text { COVERED } \\
\text { Final }\end{array}$} \\
\hline \multicolumn{3}{|c|}{$\begin{array}{l}\text { 4. TTLE ANDSUBTITLE } \\
\text { A Closer Look at 804: A Summary of Considerations for DoD Program Managers }\end{array}$} & \multicolumn{2}{|c|}{ 5. FUNDINGNUMBERS } \\
\hline \multicolumn{5}{|l|}{$\begin{array}{ll}\text { 6. } & \text { AUTHOR(S) } \\
& \text { Stephany Bellomo }\end{array}$} \\
\hline \multicolumn{3}{|c|}{$\begin{array}{l}\text { PERFORMNG ORGANZATION NAME(S) AND ADDRESS(ES) } \\
\text { Software Engineering Institute } \\
\text { Carnegie Mellon University } \\
\text { Pittsburgh, PA } 15213\end{array}$} & \multicolumn{2}{|c|}{$\begin{array}{l}\text { 8. PERFORMNG ORGANZATION } \\
\text { REPORT NUMBER } \\
\text { CMU/SEI-2011-SR-015 }\end{array}$} \\
\hline $\begin{array}{l}\text { 9. SPONSORING/MONTORINGAGE } \\
\text { HQ ESC/XPK } \\
5 \text { Eglin Street } \\
\text { Hanscom AFB, MA 01731-21. }\end{array}$ & ME(S) AND ADDRESS(ES) & & \multicolumn{2}{|c|}{$\begin{array}{l}\text { 10. SPONSORING/MONTORING } \\
\text { AGENCY REPORT NUMBER }\end{array}$} \\
\hline \multicolumn{5}{|l|}{ 11. SUPPLEMENTARY NOTES } \\
\hline \multicolumn{3}{|c|}{$\begin{array}{l}\text { 12A DISTRIBUTION/AVAILABIUTY STATEMENT } \\
\text { Unclassified/Unlimited, DTIC, NTIS }\end{array}$} & \multicolumn{2}{|c|}{ 12B DISTRIBUTIONCODE } \\
\hline \multicolumn{5}{|c|}{$\begin{array}{l}\text { This report examines Section } 804 \text { National Defense Authorization Act (NDAA) for } 2010 \text { and related guidance documents through the } \\
\text { lens of the Department of Defense (DoD) Information Technology (IT) Program Manager. The information in this report is intended to } \\
\text { help the program manager to begin to reason about building expertise, changing internal processes, and leveraging new toolsets to } \\
\text { adapt to the new IT acquisition process. }\end{array}$} \\
\hline \multicolumn{3}{|c|}{$\begin{array}{l}\text { 14. SUBJECT TERMS } \\
\text { agile, Section } 804 \text {, iterative lifecycle }\end{array}$} & \multicolumn{2}{|c|}{$\begin{array}{l}\text { 15. NUMBEROF PAGES } \\
41\end{array}$} \\
\hline \multicolumn{5}{|l|}{ 16. PRICE CODE } \\
\hline $\begin{array}{l}\text { 17. SECURTYY CLASSIFCATIONOF } \\
\text { REPORT } \\
\text { Unclassified }\end{array}$ & $\begin{array}{l}\text { 18. SECURITY CLASSIFCATION } \\
\text { OFTHISPAGE } \\
\text { Unclassified }\end{array}$ & $\begin{array}{l}\text { 19. SE } \\
\text { OF } \\
\text { Un }\end{array}$ & ICATION & $\begin{array}{l}\text { 20. LMTATIONOF } \\
\text { ABSTRACT } \\
\text { UL }\end{array}$ \\
\hline
\end{tabular}

